\title{
Implementation of E-Budgeting as an Effort of the Enhancement of Transparency and Accountability in the Government of Binjai City in North Sumatra
}

\author{
Anggi Pratama Nasution ${ }^{1}$ and Atika ${ }^{2}$ \\ ${ }^{1}$ University of Pembangunan Panca Budi Medan, Indonesia \\ ${ }^{2}$ University of Pembangunan Panca Budi Medan, Indonesia
}

\begin{abstract}
This research is intended to the Government at Binjai City of North Sumatra. Application of e-governance at regional work unit (SKPD) aims to strive the improvement of work performance based on several principles on good corporate governance (GCG) such as transparency and accountability on the government of Binjai City. Furthermore, this test is done by taking data to use questioners for all regional work (SKPD) in Binjai City. There are 52 people as budget user or author then the data is processed using some descriptive analysis methods. The result of research stated that even though the relation e budgeting is low with the accountability and transparency but the level of achievement of the use e-budgeting has been reached well in attempting to increase the function of transparency and accountability so it is concluded that the role of system e-budgeting in increasing value of transparency and accountability on the government of Binjai City has been achieved.

Keywords: Transparency, Accountability and E-Budgeting
\end{abstract}

\section{Introduction}

In Indonesia, State Financial Management is based on Act Number 13 of 2006 and based on the Minister of Home Affairs Regulation Number 51 of 2010 Supervision Guidelines for the Implementation of Regional Government. Based on this, we can see that the regional government in carrying out its function to lead to Good Corporate Governance (GCG) can be guided on its constitution.

Nowadays, Implementation of several laws at Regional Government has not been main reference in organizing Good Corporate Governance (GCG), especially in the field of budget management. In Indonesia, the impact of regional autonomy law, number 22 of 1999 experiences significant enough development. This can be seen from some matters such as the preparation of Regional Government which has not been sufficient in managing its budget especially those which related with technology system. Furthermore, the policy and strategy of national development e-Government demands a Regional Government in Indonesia to adjust to its policy based on presidential instruction number 3 of 2003. Binjai City of North Sumatra Province is one of the cities in Indonesia which recently launches e-budgeting system.

Thus, application design of budget system software based on electronic (e-Budgeting), is also part of $\mathrm{e}-$ Government that is in accordance with government regulation to help and simplify in managing guidance data for preparation of the work plan and budget of regional work unit (RKA-SKPD), it is to be made as a worthy and valid budget submission document for RKA-SKPD so it can be used to support managerial decision in organizing estimates and regional income (APBD).

The Regional Revenue and Expenditure Budget are also policy instruments, a regional budget that occupies a central position in the development of capability and effectiveness of local government .Regional budget should be used as a tool to determine the amount of income and expenditures, for making decisions and planning development, as well as expenditure authority in the future.

Principles of Accountability and Transparency in some previous literature are still a topic of discussion that develops where the research itself will be the link between accountability and transparency. This study focused on budgeting but limited to the availability of information about the budget that can be accessed as widely as possible by the community, compliance with existing regulations, and how the form of government accountability in budgeting as well as the extent to 
which the community can participate both directly and indirectly in budgeting. So, it needs either an element or role in the application good corporate governance (GCG).

Performance-based budgeting. The budget is a plan of the regional government which includes plans for revenue and expenditure within a certain period. The budget must be managed properly so the set goals can be achieved. According to Pramono H, et al. (2010: 488), budget means: "Statement of estimated performance to be achieved during a certain period that is stated in financial measures". This means that the budget is the amount of costs that will be used in achieving performance in a certain period. Whereas according to the Government Regulation of the Republic of Indonesia Number 24 of 2005 concerning Government Accounting Standards states that: The budget is a guideline for actions that will be implemented by the government including plans for income, expenditure, transfers, and measured financing in units of money that is arranged systematically based on certain classification for a period.

Thus, it can be interpreted that budget in public organization, especially government, is a complex stage because of budgeting in the government related to the determination of the amount of fund allocation for each program or activity that will be carried out in a period of government. This is the same as Whicker's statement (2002: 1359) that "the budget is used to implement both economic policy goals and specific program needs.

Budget is as a tool of management that plays an important role because it can plan, organize and evaluate the course of an activity. According to Mardiasmo $(2002 ; 61)$ suggests that the budget is a statement regarding performance estimation that should be achieved during the specified certain period that will be stated in financial measures, while budgeting is a process or method for preparing a budget. "Budget is a work plan of a company that is arranged for one-year period based on programs that have been set to achieve company goals. While the definition of the budget according to Sony Yuwono, et al (2005: 27) is: "A detailed plan is stated formally in quantitative terms, usually it is in unit of money (financial planning) to show acquisition and use of organizational resources. "Budget is a breakdown of acquisition and use of resources which owned and formally formulated as well as stated in unit of money. The budget is also called as an organization's financial planning.

According to Darise (2008: 146), performance-based budgeting is a method of budgeting which is carried out by considering the relationship between outputs and expected outcomes of activities besides programs including efficiency in achieving the output of these results. The budget cycle includes four stages which are expressed according to Mardiasmo (2009: 70) which consists of:

a. Preparation phase

In the budget preparation stage, the estimated expenditure is based on estimated income available. It is based on the vision, mission, and goals of the organization. In this regard, it should be noted that before approving the estimated expenditure, the income estimation should be done first.

b. Ratification Phase

This stage is a stage that involves a complicated political process. Executive leaders are required to have integrity and high mental readiness. This is important because the chief executive must have the ability to answer and provide rational arguments for all questions and objections from the legislature.

c. Implementation Phase

In the implementation phase of the budget, the most important thing that is considered by public finance managers is the ownership of the management of control and accounting information system. Public finance managers in this case are responsible for creating an adequate and reliable accounting system for planning and controlling the agreed budget, and even they are relied on the budget preparation stage for the next period.

d. Reporting and Evaluation Phase

The preparation, ratification and implementation phase of the budget are related to the budget operational aspects, while the reporting and evaluation stages are related to accountability aspects. If 
the implementation phase has been supported by a good accounting and management control system, it is expected that the reporting and evaluation phase will not encounter many problems.

Regional budgets or APBD are the main policy tools for local governments. As a policy tool, the regional budget occupies a central position in the development of capability and effectiveness of local government. The process of drafting the Regional Budget (APBD) is divided into 4 stages, namely:

a. $\quad$ Preparation of APBD General Policy and Temporary Budget Priority Ceiling

b. Preparation of SKPD Budget Work Plans

c. Preparation of RAPBD

d. APBD Determination and Discussion

Furthermore, the results of an integrated budget plan are submitted to the regional head for approval and then delivered to the Regional Representative Council (DPRD). Submission to DPRD is in the form of a Regional Budget (RAPBD) to be discussed and approved by DPRD, so that its determination can be set forth in regional regulations (Perda).

In accordance with the explanatory paragraph contained in the Government Regulation Number 58 of 2005 concerning Regional Financial Management explaining the Planning and Budgeting stated that: APBD is an instrument that will guarantee the creation of discipline in the decision-making process related to regional income and expenditure policies. To ensure that the APBD can be prepared and implemented properly and correctly, then in this regulation is set the administrative foundation in the management of regional budgets which regulate among procedures and technical budgeting that must be followed in an orderly and compliant manner. In addition, in the framework of budget discipline, the preparation both "income" and "shopping" must also refer to the rules or guidelines that underlie what the Act is, Government Regulation, Ministerial Decree, Regional Regulation or Decree of the Regional Head. Therefore, in the process of drafting APBD, the regional government must follow the administrative procedures that stipulated.

Some principles in budget discipline also need to pay attention in the preparation of regional budgets, they are (1) planned income is a rationally measured estimate that can be achieved for each source of income, while expenditure budget is the highest limit of spending; (2) Budgeting for expenditures must be supported by the availability of certainty and unjustified revenues to carry out activities that are not yet available or insufficient budget in APBD / Amendments to APBD; (3) All regional revenues and expenditures within the relevant fiscal year must be included in APBD and carried out through the Regional General Cash account.

Transparency. Transparency is built based on free information flow. All government processes, institutions, and information need to be accessed by interested parties and the information available must be enough to be understood and monitored. There are several notions of public transparency, namely: Andrianto (2007) states that transparency is: "Openness in earnest, comprehensively, and provides a place for active participation from all levels of society in the process of managing public resources." According to Hafiz (2010) transparency is "Openness and honesty to the public based on the consideration that the community has the right to know the accountability of the government openly and thoroughly in the entrusted resources and its compliance with the legislation."

The above definition can be said that transparency is the government's openness to the public to access information based on the consideration that the community has the right to know the accountability of the government openly and comprehensively.

Transparency dimension. The principle that guarantees access or freedom for each person to obtain information about the administration of government, such as information on policies, the process of making, implementing, and the results achieved. According to Krina (2003), this principle emphasizes two aspects:

a. Public communication by the government

b. Community rights to access information

According to Krina (2003), the indicators of transparency are as follows:

a. Provision of clear information about responsibility 
b. Prepare a complaint mechanism if there are rules that are violated or requested to pay bribes

c. Ease to access information

d. Increasing information flow through collaboration with mass media and non-government institutions

Accountability. According to Suherman (2007) Accountability is the proper functioning of all the components running the activities of the company, it is suitable with the task and their respective authorities.

Next the researcher will explain the definition of accountability. Mardiasmo (2004) states that definition of accountability is the obligation of the parties to the trustee (agent) to provide accountability, present, report, and disclose all activities that become the responsibility of the trustee who has the right and authority."

From the above two definitions, it can be said that accountability is the responsibility for everything done by the leader or institution that gives authority and accountability, this is a principle that guarantees that each activity of an organization or individual can be accounted openly to the public.

Based on some accountability seen from various points of view, accountability can be interpreted as an obligation to present and report activities of a person or institution, especially the field of financial administration to higher parties. Accountability in the context of governance means accountability which has one of the characteristics of applied good governance. This thinking comes from the thought of public administration which is an issue towards clean government. Accountability seen from a control point of view is an action on achieving goals.

Nature of Accountability. Government financial statements must provide information that can be used by users of financial statements to assess the accountability of government in making economic, social and political decision. Accountability is defined as the relationship among the parties holding control and managing the entity with those who have formal power on the controlling party. In this case, it is also necessary for a third party to be accountable to provide explanations or reasonable reasons for all activities which are carried out. In addition to the business results obtained associated with the implementation of a task and the achievement of a goal.

In the context of governance, government accountability cannot be known without the government informing the public about information regarding the collection of resources and sources of public funds and their use. Accountability can be viewed from a variety of perspectives. From an accounting perspective, the American Accounting Association states that the accountability of a government entity can be divided into four groups, they are:

a. Financial resources

b. Compliance with legal rules and administrative policies

c. Efficiency and economy of an activity

d. The results of government programs and activities that are reflected in the achievement of goals, benefits and effectiveness.

From a functional perspective, accountability is seen as a level with five different stages starting from more numerous stage that requires objective measures (legal compliance) to a stage that requires more subjective measures. These stages are:

a. Probity and legality accountability. This involves accountability for the use of funds in accordance with the approved budget and the applicable laws and regulations (compliance).

b. Process accountability. In this case, processes, procedures or measures are used in carrying out the activities specified (planning, allocating and managing).

c. Performance accountability. This level shows whether the activities carried out are efficient (economy and efficient).

d. Accountability programs. Here will be highlighted the determination and achievement of the stated goals (outcomes and effectiveness).

e. Policy accountability. In this stage, the selection of various policies that will be applied or not (value). 
The hypothesis is a concrete explanation of behavior, phenomena or certain circumstances that have occurred or will occur (Erlina and Mulyani, 2007). Based on the problem formulation, literature review and conceptual framework, the hypotheses in this study are as follows:

a. The role of the e-budgeting system in increasing the value of Transparency in the government of Binjai City has been achieved.

b. The role of the e-budgeting system in increasing the value of Accountability in the government of Binjai City has been achieved.

c. Empirically the writer explains the form of the textual framework in Figure 1 below:

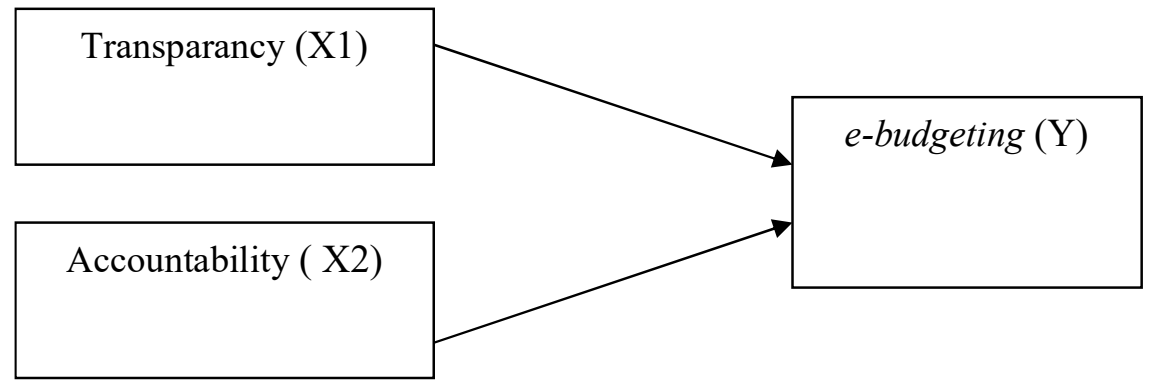

Figure 1. The conceptual framework

Based on the picture above, the hypothesis is

a. How to implement E-Budgeting in improving transparency function.

b. How to implement E-Budgeting in improving accountability function.

\section{Research Methodology}

This study can be considered as a causal research, it is to see the relationship of several uncertain variables.

The source of the data in this study were 52 Budget Users or Proxies in each Regional Work Unit (SKPD) in the government of Binjai City of North Sumatra Province in 2018 .

Descriptive statistics are generally used by researchers to provide information about the characteristics of the main research variables and the demographic data of respondents. This study uses descriptive statistics consisting of the average, standard deviation, minimum and maximum of the answers obtained from the questionnaire. In addition, Basic of making decision in the chi-square test can be done by looking at the Chi-square test output value. In decision making will be guided by the value of Asymp.Sig with a critical limit of 0,05 by looking at the value of chi-square test with chi square table.

\section{Result and Discussion}

The following are the results of the Reliability Test. 
Table 1. Validity Test Results

\begin{tabular}{|c|l|c|c|c|}
\hline Variable & Instrument Item & $r$ Count & R Table & Results \\
\hline E-Budgeting & E-Budgeting & 0.416 & 0,232 & Valid \\
\cline { 2 - 5 } & E-Budgeting & 0.561 & 0,232 & Valid \\
\cline { 2 - 5 } & E-Budgeting & 0.306 & 0,232 & Valid \\
\cline { 2 - 5 } & E-budgeting & 0.347 & 0,232 & Valid \\
\cline { 2 - 5 } & E-Budgeting & 0,308 & 0,232 & Valid \\
\cline { 2 - 5 } & E-Budgeting & 0.598 & 0,232 & Valid \\
\cline { 2 - 5 } & E-Budgeting & 0.265 & 0,232 & Valid \\
\hline Accountability & Accountability & 0.497 & 0,232 & Valid \\
\cline { 2 - 5 } & Accountability & 0.379 & 0,232 & Valid \\
\cline { 2 - 5 } & Accountability & 0.442 & 0,232 & Valid \\
\cline { 2 - 5 } & Accountability & 0.540 & 0,232 & Valid \\
\cline { 2 - 5 } & Accountability & 0.481 & 0,232 & Valid \\
\cline { 2 - 5 } & Accountability & 0.361 & 0,232 & Valid \\
\cline { 2 - 5 } & Accountability & 0.390 & 0,232 & Valid \\
\cline { 2 - 5 } & Accountability & 0.235 & 0,232 & Valid \\
\hline Transparency & Transparency & 0.317 & 0,232 & Valid \\
\cline { 2 - 5 } & Transparency & 0.423 & 0,232 & Valid \\
\cline { 2 - 5 } & Transparency & 0.482 & 0,232 & Valid \\
\cline { 2 - 5 } & Transparency & 0.428 & 0,232 & Valid \\
\cline { 2 - 5 } & Transparency & 0.352 & 0,232 & Valid \\
\cline { 2 - 5 } & Transparency & 0.385 & 0,232 & Valid \\
\cline { 2 - 5 } & Transparency & 0.582 & 0,232 & Valid \\
\hline
\end{tabular}

From the table above can be seen that the value of validity for all questions E-Budgeting, Accountability and Transparency everything is valid .

The following are the results of the Reliability Test.

Table 2. Reliability Test Results

\begin{tabular}{|c|c|c|c|}
\hline Variable & $\begin{array}{c}\text { Alpha } \\
\text { Cronbach's }\end{array}$ & $\begin{array}{c}\text { Reliability } \\
\text { Limit }\end{array}$ & Results \\
\hline $\begin{array}{c}\text { Implementation of E- } \\
\text { Budgeting }\end{array}$ & 0,606 & 0.6 & Reliable \\
\hline Accountability & 0,643 & 0.6 & Reliable \\
\hline Transparency & 0,630 & 0.6 & Reliable \\
\hline
\end{tabular}

Based on the above article can be seen in 30 statement items, it is known that the value of all the variables in Cronbach's Alpha is $>2.30$ so it can be concluded that the constructs of the variables through are reliable and acceptable.

The implementation of E-Budgeting in the government of Binjai City is shown in the table below: 
Table 3. Descriptive Statistics of E-Budgeting Implementation IMPLEMENTATION EBUDGETING

\begin{tabular}{|c|c|c|c|c|c|}
\hline & & Frequency & Percent & $\begin{array}{c}\text { Valid } \\
\text { Percent }\end{array}$ & $\begin{array}{c}\text { Cumulative } \\
\text { Percent }\end{array}$ \\
\hline \multirow[t]{3}{*}{ Valid } & Has been achieved & 28 & 53.8 & 53.8 & 53.8 \\
\hline & $\begin{array}{l}\text { highest } \\
\text { achievement }\end{array}$ & 24 & 46.2 & 46.2 & 100.0 \\
\hline & Total & 52 & 100.0 & 100.0 & \\
\hline
\end{tabular}

From the table above, it is known that $54.8 \%$ of respondents said that E-Budgeting Implementation has been achieved and $46.2 \%$ of respondents stated E-Budgeting Implementation has been achieved in high level achievement in the government of Binjai City.

The accountability descriptive statistics in the Government of Binjai City are shown in the table below:

Table 4. Accountability Descriptive Statistics

\begin{tabular}{|l|r|r|r|r|}
\hline & Frequency & Percent & Valid Percent & $\begin{array}{c}\text { Cumulative } \\
\text { Percent }\end{array}$ \\
\hline Valid fairly achieved & 19 & 36.5 & 36.5 & 36.5 \\
& 33 & 63.5 & 63.5 & 100.0 \\
$\begin{array}{l}\text { Has been } \\
\text { achieved }\end{array}$ & 52 & 100.0 & 100.0 & \\
\hline
\end{tabular}

From the table above, it is known that $36.5 \%$ of respondents mentioned that accountability implementation is fairly achieved and $63.5 \%$ of respondents stated accountability has been reached in the government of Binjai City.

Descriptive Statistics of Transparency in the Government of Binjai City shown in the table below:

Table 5. Transparency Descriptive Statistics

\begin{tabular}{|l|r|r|r|r|}
\hline & Frequency & Percent & $\begin{array}{c}\text { Valid } \\
\text { Percent }\end{array}$ & $\begin{array}{c}\text { Cumulative } \\
\text { Percent }\end{array}$ \\
\hline Valid fairly achieved & 7 & 13.5 & 13.5 & 13.5 \\
$\begin{array}{l}\text { Has been } \\
\text { achieved }\end{array}$ & 45 & 86.5 & 86.5 & 100.0 \\
Total & 52 & 100.0 & 100.0 & \\
\hline
\end{tabular}

From the table above, it is known that by $13,5 \%$ of respondents stated that the implementation of transparency is fairly reached and $86,5 \%$ of respondents stated that Transparency has been achieved in the government of Binjai City .

The implementation of E-Budgeting in reminding the accountability to the government in Binjai City is seen in the table below: 
Table 6. Crosstab Implementation of E-Budgeting in Improving Accountability

\begin{tabular}{|c|c|c|c|}
\hline & \multicolumn{2}{|c|}{ IMPLEMENTASI_EBUDGETING } & \\
\hline & $\begin{array}{l}\text { Has been } \\
\text { achieved }\end{array}$ & $\begin{array}{c}\text { Highest } \\
\text { Achievement }\end{array}$ & Total \\
\hline $\begin{array}{r}\text { ACCOUNTABILITY Fairly } \\
\text { achieved }\end{array}$ & 9 & 10 & 19 \\
\hline $\begin{array}{l}\text { Has } \\
\text { been } \\
\text { achieved }\end{array}$ & 19 & 14 & 33 \\
\hline Total & 28 & 24 & 52 \\
\hline
\end{tabular}

From the table above, it is known that there are 9 (nine) people who have achieved the implementation of E-Budgeting, but accountability is quite achievable and there are 10 (ten) people very well achieved in the implementation of E-Budgeting but the Accountability is quite achieved Furthermore, there are 19 (nineteen) people who have achieved in the implementation of E-Budgeting and their accountability has also been achieved and there are 14 (fourteen) people who have achieved the implementation of E-Budgeting, but their accountability has been achieved.

To find out the level of influence between E-Budgeting Implication on Accountability, it can be seen from the Chi Square data test below:

Table 7. Chi-Square Test Implementation of E-Budgeting in Improving Accountability

\begin{tabular}{|l|r|r|r|r|r|}
\hline & Value & df & $\begin{array}{c}\text { Asymp. Sig. (2- } \\
\text { sided) }\end{array}$ & $\begin{array}{r}\text { Exact Sig. (2- } \\
\text { sided) }\end{array}$ & $\begin{array}{c}\text { Exact Sig. (1- } \\
\text { sided) }\end{array}$ \\
\hline Pearson Chi-Square & $.506^{\mathrm{a}}$ & 1 & .477 & & \\
Continuity Correction $\mathrm{b}$ & .178 & 1 & .673 & & \\
Likelihood Ratio & .505 & 1 & .477 & & .688 \\
Fisher's Exact Test & & & & & \\
Linear-by-Linear & .496 & 1 & .481 & & \\
Association & 52 & & & & \\
N of Valid Cases ${ }^{b}$ & & & & & \\
\hline
\end{tabular}

a. 0 cells $(.0 \%)$ have expected count less than 5 . The minimum expected count is 8.77 .

b. Computed only for a $2 \times 2$ table

In the explanation above, it is known that the Asymp.Sig value is 0.477 which indicates that $0.477>$ 0.05 means that there is no influence between the implementation of E-Budgeting on accountability in the government of Binjai. Furthermore, the degree of closeness between the effect of E-Budgeting implementation on accountability in the government of Binjai City is outlined in the table below:

Table 8. Symmetric Measures of the degree of closeness of E-Budgeting implementation in improving accountability

\begin{tabular}{|ll|r|r|}
\hline & Value & Approx. Sig. \\
\hline Nominal by nominal & Contingency Coefficient & .098 & .477 \\
N of Valid Cases & & 52 & \\
\hline
\end{tabular}


In the table above is obtained contingency coefficient value of 0.098 which indicates the level of closeness of the implementation of E-Budgeting to the low accountability value to the Government in Binjai.

The implementation of E-Budgeting in reminding the transparency of the government in Binjai City is seen in the table below:

Table 9. Crosstab Implementation of E-Budgeting in Improving Transparency

\begin{tabular}{|c|r|r|r|}
\hline \multirow{2}{*}{} & \multicolumn{2}{|c|}{ IMPLEMENTASI_EBUDGETING } & \\
\cline { 2 - 4 } & Has been achieved & Highest Achievement & Total \\
\hline TRANSPARENCY Fairly achieved & 2 & 5 & 7 \\
Has been & 26 & 19 & 45 \\
achieved & 28 & 24 & 52 \\
\hline
\end{tabular}

From the table above, it is known that there are 2 (two) people who have achieved the implementation of E-Budgeting, but the transparency is quite achievable and there are 5 ( five ) people who are very achievable to do the implementation of E-Budgeting, but the transparency is quite achieved .

Furthermore, there are 26 (twenty-six) people who have achieved the implementation of E-Budgeting and its transparency has also been achieved and there are 19 (nineteen) people who have achieved the implementation of E-Budgeting, but the transparency has been achieved.

To determine the level of influence between E-Budgeting implication on transparency can be seen from the Chi Square data test below:

Table 10. Chi-Square Test Implementation of E-Budgeting in Improving Transparency.

\begin{tabular}{|l|r|r|r|r|r|}
\hline & Value & Df & $\begin{array}{c}\text { Asymp. Sig. (2- } \\
\text { sided) }\end{array}$ & $\begin{array}{c}\text { Exact Sig. (2- } \\
\text { sided) }\end{array}$ & $\begin{array}{c}\text { Exact Sig. (1- } \\
\text { sided) }\end{array}$ \\
\hline Pearson Chi-Square & 2,079 a & 1 & .149 & & \\
Continuity Correction b & 1,070 & 1 & .301 & & \\
Likelihood Ratio & 2,114 & 1 & .146 & & .227 \\
Fisher's Exact Test & & & & & \\
Linear-by-Linear & 2,039 & 1 & .153 & & \\
Association & 52 & & & & \\
N of Valid Cases b & & & & \\
\hline
\end{tabular}

a. 2 cells $(50,0 \%)$ have expected count less than 5 . The minimum expected count is 3,23 .

b. Computed only for a $2 \times 2$ table

In the explanation of the table above, it is known that the Asymp.Sig value is 0.149 which indicates that $0.149>0.05$ means that there is no influence between the implementation of E-Budgeting on transparency in the government of Binjai City. Furthermore, the level of closeness between the Effect of E-Budgeting implementation on transparency in the Government of Binjai City is outlined in the table below: 
Table 11. Symmetric Measures of the degree of closeness of E-Budgeting implementation in increasing transparency

\begin{tabular}{|c|c|c|c|}
\hline & & Value & Approx. Sig. \\
\hline $\begin{array}{l}\text { Nominal by } \\
\text { nominal }\end{array}$ & $\begin{array}{l}\text { Contingency } \\
\text { Coefficient }\end{array}$ & .196 & .149 \\
\hline $\mathrm{N}$ of Valid $\mathrm{C}$ & & 52 & \\
\hline
\end{tabular}

In the table above is obtained contingency coefficient value of 0.196 which indicates the level of closeness to the implementation of E-Budgeting to the low value transparency on Government in Binjai.

A system is essentially formed to facilitate an organization in carrying out the process of implementing its organizational activities. Furthermore, for the stages, each system itself must be able to adjust and develop according to the needs of each user. From the results of the study, it was stated that there was no effect of E-Budgeting Implementation in improving Accountability and Transparency, it happened because the implementation of E-Budgeting in the government of Binjai City had only been running for 1 (one) year so the size of its influence could not be assessed maximally and it was clarified with the results of the relationship between E-Budgeting in increasing accountability and the low value transparency.

In addition, prior to the use of e-budgeting, the government of Binjai has received the results of audit opinions from good BPK, namely 2016, Unqualified (WTP) and 2015, Fair with Exception (WDP).

Furthermore, even though the relationship is low, the level of achievement of the use of e-budgeting has been very well achieved in an effort to improve the function of accountability and transparency, it means that each OPD (Regional Organization) of Binjai City has made maximum efforts in realizing the use of e-budgeting in achieving accountability and value of transparency in each OPD of the government of Binjai City.

\section{Conclusion}

The implementation of the e-budgeting system in increasing the value of transparency in the Government of Binjai City has been achieved. The implementation of the e-budgeting system in increasing the value of accountability in the government of Binjai City has been achieved.

The government of Binjai City is expected to be able to improve the function of E- Budgeting for all aspects of the needs. The government of Binjai City needs to carry out the process of monitoring the evaluation periodically in order to strengthen the results of the expectation of implementing the ebudgeting system in the city.

\section{References}

Andrianto, Nico. 2007. Good Government : Transparansi dan Akuntabilitas Publik melalui eGoverment. Palangkaraya. Bayu Medan.

Darise, Nurlan. 2008. Akuntansi Keuangan Daerah (Akuntansi Sektor Publik). Jakarta: PT INDEKS. Ghozali, Imam. 2011. “Aplikasi Analisis Multivariat dengan Program IBM SPSS 19 Edisi 5". Badan Penerbit Universitas Diponegoro. Semarang.

Hafiz, Abdul Tanjung.2010. Akuntansi, Tranparansi dan Akutabilitas Keuangan Publik. (Sebuah Tantangan).

Instruksi Presiden No. 3 tahun 2003 tentang Kebijakan dan Strategi Nasional Pengembangan eGovernment

Krina, P. 2003. Indikator dan alat ukur prinsip akuntabilitas transparansi dan partisipasi. Jakarta : Sekretariat Good Publik Governance. Badan Perencanaan Pembangunan Nasional.

Mardiasmo.2004. Perwujudan Transparansi dan Akuntabilitas Publik Melalui Akuntansi Sektor Publik. Suatu Sarana Good Governance 
Mardiasmo. 2009. Akuntansi Sektor Publik. Yogyakarta: Andi.

Permendagri Nomor 13 Tahun 2006 Tentang Pedoman Pengelolaan Keuangan Daerah.

Permendagri Nomor 51 Tahun 2010 tentang Pedoman Pengawasan Penyelenggaraan Pemerintah Daerah.

Peraturan Pemerintah Nomor 58 Tahun 2005 tentang Pengelolaan Keuangan Daerah.

Pramono H, dkk. 2010. Pengelolaan Keuangan Daerah. Jakarta: Salemba Empat.

Sa'adah, Binti. 2015. Akuntabilitas dan Transparansi Anggaran Melalui E - Goverment (Studi Tentang Penganggaran di Pemerintah Daerah Kabupaten Bilitar).

Toha, Suherman.2007. Penelitan Masalah Hukum Tentang Penerapan Good Coorporate Governance Pada Dunia Usaha. Badan Pembina Hukum Nasional Departemen Hukum dan Hak Asasi Manusia.

Undang - Undang Otonomi Daerah No. 22 Tahun 1999.

Umar, Husein, 2008, Desain Penelitian Akuntansi Keprilakuan., PT. Raja Grafindo Persada. Jakarta

Whicker, Marcia Lynn. 2002, Federal Deficit and Financing the National Debt. In: Handbool of Fiscal Policy. New York: Marcel Dekker Inc.

Yuwono, S, I.T. Agus, dan Hariyadi. 2005. Penganggaran Sektor Publik, Pedoman Praktis, Penyusunan, Pelaksanaan dan Pertanggungjawaban APBD (Berbasis Kinerja). Bayumedia Publising, Malang. 